\title{
nature
}

\section{No gas, please, in the Middle East}

Last week's conference on chemical weapons was ruffled by the flawed argument that Israel's adversaries need them to counter Israel's nuclear pretensions.

Public declarations of good intentions are cheap, decisions to put them into practice much more costly. This familiar truth seems to have been amply confirmed at last week's conference on chemical weapons (see page 199), held in Paris under the now-unfamiliar auspices of UNESCO. The 149 governments at Paris seem readily to have agreed that the best way to avoid the use of chemical weapons is to abolish them, but their joint declaration is deficient in two important ways. First, it fails to say much about the issue that has impeded the negotiations at Geneva for the past eight years, that of the verification of an agreement not to manufacture gases of the kind that can be loaded into munitions, although such a general conference cannot be blamed for that. Second, it fails to specify with clarity the dangers of the precedent set by Iraq during its recent war with Iran, when phosgene or a near relative seems to have been used against troops and civilian populations. Instead, it managed to give general currency to the notion that chemical weapons are a kind of natural counterpoise to nuclear weapons and should be legitimized as such.

That doctrine is profoundly mistaken, but seems to have been made with some force by Middle East states other than Iraq. So long as Israel has nuclear weapons (a plausible but untested assumption), is it not just that its potential adversaries should have access to chemical weapons as a kind of counterpoise? The argument is seductive, but false. The truth is that chemical weapons are not, except in the most symbolic sense, a counterpoise to nuclear weapons. Instead, they are a quite separate nuisance of a most serious kind.

Suppose that Israel is indeed a cryptic nuclear power, with a stock of more than 50 nuclear weapons - so much is the plausible inference from the harsh treatment by the Israeli courts last year of the technician from the Ramona nuclear complex who spilled the beans about plutonium extraction on the site. What use could Israel make of these weapons, which of necessity have not been tested? If Israel were in open conflict with its neighbours, and were so much in danger of defeat that the old Israeli nightmare of being driven into the sea seemed a reality, it is in principle possible that it could save itself from extinction by threatening to use nuclear weapons against the capitals of its adversaries. Earlier use of nuclear weapons, or the threat thereof, would do more harm than good to the Israeli cause previously friendly governments would be compelled to withdraw support, and worse. But as things are, the possibility that Israel might be extinguished as an independent state would bring friendly governments rallying round long before Israel would rationally need to threaten nuclear retaliation. Thus Israel's nuclear weapons have a military function only in the extreme case that it has lost all its friends and is about to lose a terminal conflict. Militarily, Israel's nuclear weapons are a kind of national suicide pill - but their more immediate political utility is that of helping to cement deals with equally threatened governments.

Chemical weapons are a different kettle of noisome fish. Little is known of the value to Iraq of the use of phosgene in the recent war (somebody should find out), but it is likely to have been marginal in strictly military terms. Soldiers (and civilians) were killed in dreadful ways, but the most substantial damage to the Iranian troops, ill-equipped with protection against gas, is likely to have been psychological. Nerve gases, such as Libya is said by the United States to be preparing to manufacture, would have been more damaging, especially to the civilian population. Their military utility against well-equipped Israeli troops would again be marginal, while their large-scale use against the unprotected population of some Israeli city would bring down on the head of the user an insupportable torrent of protest and constraint. But that does not mean that the prospect that nerve gases will become more widely available is of no concern. These materials would evidently be of great value in surprise attacks against small groups of people, whether troops or not. And, given the ubiquity of the trade in arms, they would undoubtedly be used in other contexts (say, in hi-jacked aircraft) well outside the Middle East.

The argument that chemical weapons are a counterpoise to Israeli nuclear weapons thus makes no sense. That does not mean that the governments in the Middle East that have raised the issue would not be within their rights in demanding that Israel should trade its putative nuclear weapons for the political and military guarantees no doubt accompanying a peace settlement in the Middle East. It may also be prudent to accept last week's demand that the scope of the Geneva negotiations should be broadened to include at least Iraq (although, with 40 participants already, the negotiations are cumbersome enough). But the argument that chemical weapons should be counted as part of a poor country's right to self-defence is paper-thin, and should be denounced as such. To make it is dangerously irresponsible for the curiosity it will excite, not only in the Middle East.

\section{Industrial illogic}

One of Britain's largest companies may disappear because, as in the parable of the talents, it has been over-thrifty.

WHETHER or not 1992 will see the eventual emergence of the true European common market advertised in the 1950 s by the Treaty of Rome, the prospect that it might has caused turmoil in what is loosely called the electronics business. Two independent sets of motives have set off a wave of industrial reorganization. European companies, recognizing that there are more of them than the European market can comfortably accommodate, are anxious to consolidate their interests, preferably across European frontiers. Second, companies from outside the European Community are seeking to establish themselves within it, not least as an insurance against the chance that common-market Europe will chauvinistically protect its industries against competitors. The latest reorganization, mostly in Britain, also points to past errors by government and business which are all too likely to be repeated in the future.

The centre of the turmoil in Britain is the General Electric Company, or GEC, which resembles in the pattern of its activity the US company called General Electric or GE, but which is only a third as big. GEC as it is owes its existence to the convic- 